\title{
Influencia de la concentración del activador sobre la cinética del proceso de activación alcalina de una escoria de alto horno
}

\author{
Influence of the activator concentration on the kinetics of the \\ alkaline activation process of a blastfurnace slag
}

Lda. A. FERNÁNDEZ -JIMENEZ y Dra. F. PUERTAS Instituto de Ciencias de la Construcción Eduardo Torroja (CSIC)

Fecha de recepción: 17-I-97

Fecha de aceptación: 27-II-97

ESPAÑA

RESUMEN

Se ha estudiado la influencia de la concentración de la disolución activante en la cinética de hidratación de una escoria granulada de alto horno, activada alcalinamente a distintas temperaturas. El activador alcal ino utilizado fiue una mezcla de water glass $\left(\mathrm{Na}_{2} \mathrm{SiO}_{3} \cdot \mathrm{nH}_{2} \mathrm{O}\right)$ con una disolución de $\mathrm{NaOH}$ (de concentracion variable). Las concentraciones finales del activador alcalino fueron: $\hat{3}, 4 y$ $5 \%$ en peso de $\mathrm{Na}_{2} \mathrm{O}$ respecto a la masa total de escoria.

El grado de reacción $(\alpha)$ se determinó a partir de valores de calor de hidratación obtenidos por calorimetria de conducción isotérmica. De los resultados obtenidos se deduce que existe un valor umbral de concentraciones en torno al $4 \%$ en peso de $\mathrm{Na}_{2} \mathrm{O}$. También para dichas concentraciones y a las temperaturas de ensayo (excepto a $25^{\circ} \mathrm{C}$ ' con un $3 \%$ en peso de $\mathrm{Na} \mathrm{O}_{2} \mathrm{O}$ ), el mecanismo que controla la reacción de hidratación para valores de $\alpha>0,5$ es la difusión. Liste proceso viene descrito por la ecuación de Jander $\left./ D_{3}-\left(1-(1-\alpha)^{1 / 3}\right)^{2} \cdots\left(k / r^{2}\right) t-0,0426\left(t / t_{0,5}\right)\right) . L a$ energía de activación obtenida para dicho proceso es del orden de $50-58 \mathrm{~kJ} / \mathrm{mol}$.
SUMMARY

The influence of activator solution concentration on hydration kinetics of an alkaline activated blast furnace slag has been studied. The alkaline activator used was a mix of waterglass $\left(\mathrm{Na}_{2} \mathrm{SiO}_{3} \cdot n \mathrm{H}_{2} \mathrm{O}\right)$ and $\mathrm{NaOH}$ solution (of variable concentration). Final activator concentrations were $3,+t$ and $5 \% \mathrm{Va}, \mathrm{O}$ wt. with respect to the slag total weight.

Degree of reaction ( $\alpha$ ) was determined from hydration heat values obtained through isothermal conduction calorimetry. From the results obtained it is deduced that a treshold value of $+\% \mathrm{Na}_{2} \mathrm{O}$ wt. exists. For those concentrations and at test temperatures (except for $25^{\circ} \mathrm{C}$ ' and $3 \% \mathrm{Na}_{2} \mathrm{O} w t$.), the mechanism controlling hydration reaction for $\alpha$ values higher than 0.5 , is a diffusion process. This process is described by Jander equation $\left.(I)_{3}=\left(1-(I-\alpha)^{1 / 3}\right)^{2} \cdots\left(k / r^{2}\right) t=0.0426\left(t / t_{0.5}\right)\right) . T$.The activation energy obtained for that process is of approximately $50-58 \mathrm{Kj} / \mathrm{mol}$.

\section{INTRODUCCIÓN}

La activación alcalina de una escoria es un proceso complejo (1) en el que inicialmente se produce la destrucción de la estructura de la escoria seguido por una policondensación y precipitación de los productos de reacción formados. Numerosos autores (2-5) consideran que este proceso de activación transcurre a

\section{INTRODUCTION}

The alkaline activation of slag is a complex process (1) in which the slag structure destruction is firstly produced followed by a policondensation and precipitation of the reaction products formed. Some authors (2-5) considered this process to occur through an heterogeneous reaction. These type of reactions are 
través de una reacción heterogénea. Este tipo de reacciones está gobernado por tres mecanismos: a) nucleación y crecimiento de las fases hidratadas, b) interacciones de phase boundary y c) difusión a través de la capa de productos de hidratación.

En un trabajo anterior (6), los autores del presente artículo, utilizando datos calorimétricos, prepusieron para grados de reacción elevados $(\alpha>0,5)$, el mecanismo que explica el proceso de activación alcalina de una escoria de alto horno.

La curva calorimétrica obtenida al activar alcalinamente una escoria, se caracteriza por presentar un primer pico, debido al proceso inicial de disolución parcial de la escoria por el activador alcalino. Este proceso de disolución es tan rápido que no siempre es posible detectar dicho pico. A continuación, en la curva calorimétrica, aparece una zona que se caracteriza por una muy baja contribución al calor total, denominándose período de inducción. Finalmente, en las curvas de velocidad de evolución de calor, aparece un segundo pico asociado a la precipitación de la mayor parte de los productos de reacción. Los datos calorimétricos procesados en el mencionado trabajo (6) se tomaron al inicio de este segundo pico. Así, se definió un valor de calor $Q^{\prime}\left(t^{\prime}\right)$ como el calor liberado al inicio de segundo pico de las curvas de velocidad de evolución de calor, es decir, a partir de la finalización del período de inducción.

El grado de reacción $\alpha$ se determinó aplicando la ecuación [1] de Stutter (7), y el de Q'max, utilizando la ecuación [2] de Knudsen (8).

$$
\alpha=Q^{\prime}\left(t^{\prime}\right) / Q^{\prime} \max \quad[1] ; 1 / P=1 / P_{1}+\left(t_{0.5} / P_{1}\right) \times(1 / t)
$$

donde $P=Q^{\prime}\left(t^{\prime}\right), P_{i}=Q^{\prime} \max$ y $t_{0,5}$ es el tiempo necesario para liberar el $50 \%$ del calor total.

La principal conclusión obtenida en estos estudios fue que el mecanismo que explica la activación alcalina de una escoria granulada de alto horno activada con una mezcla de waterglass $\left(\mathrm{Na}_{2} \mathrm{SiO}_{3} \cdot \mathrm{nH}_{2} \mathrm{O}\right)$ con una disolución de $\mathrm{NaOH}$ (la concentración final de la mezcla fue de un $4 \%$ en peso de $\mathrm{Na}_{2} \mathrm{O}$, respecto a la escoria), para valores de $\alpha$ $>0,5$, es de difusión. Este proceso viene descrito por la ecuación de Jander. La energía de activación del proceso es del orden de $57,6 \mathrm{~kJ} / \mathrm{mol}$.

El objetivo del presente trabajo es determinar qué influencia tiene la concentración de la disolución activante sobre el mecanismo que controla el proceso de activación alcalina de las escorias granuladas de alto horno a distintas temperaturas. Como activador se utilizó una disolución de $\mathrm{wg}+\mathrm{NaOH}$, con distintas concentraciones de $\mathrm{Na}_{2} \mathrm{O}(3,4$ y $5 \%$ en peso). Las temperaturas de reacción fueron $25,35,45$ y $60^{\circ} \mathrm{C}$. governed by three mechanisms: a) nucleation and growth of hydrated phases, b) phase boundary interactions and c) diffusion through hydration products layer.

In a former work (6), the authors of the present work proposed, using calorimetric data, a mechanism explaining the slag alkaline activation for high reaction degrees $(\alpha>0.5)$.

When the slag is activating, the calorimetric curve obtained is characterised by the presence of a first peak due to the initial partial dissolution of the slag by the alkaline activator. This dissolution process is very fast and it is not always possible to be detected. In the calorimetric curve, an area appears with small contribution to the total heat called induction period. Finally, in the rate evolution curves, a second peak appears related to the precipitation of most of the reaction products. (alorimetric data processed in the mentioned work (6) were taken at the beginning of this second peak, this is, when the induction period was finished.

Reaction degree was determined applying Schutter equation [1] and Q'max was determined applying Knudsen equation (8).

Where $P=Q^{\prime}(t), P, Q$ max and $t_{0.5}$ is the time necessary for $50 \%$ of the total heat to be released.

The main conclusion obtained in these studies was that the mechanism explaining the alkaline activation of a blast furnace slag with a mixture of waterglass and $\mathrm{NaOH}$ (final concentration of the mixture was $4 \% \mathrm{wt}$. of $\mathrm{Na}_{2} \mathrm{O}$ ), for values higher than $\alpha>0.5$, was a diffusion mechanism. This process is described by Jander equation. Activation energy of the process is of about $57.6 \mathrm{~kJ} / \mathrm{mol}$.

The objective of the present work is to determine the influence of activator solution concentration on the mechanism controlling the alkaline activation of blast furnace slags at different temperatures. A solution of waterglass and $\mathrm{NaOH}$ with different $\mathrm{N}$ concentrations. was taken as activator. Reaction temperatures were 25. 35,45 and $60^{\circ} \mathrm{C}$. 


\section{EXPERIMENTAL}

Se utilizó una escoria granulada de alto horno procedente de Avilés (Asturias, España), con una composición química de: $42,80 \%$ de $\mathrm{CaO}, 36,10 \%$ de $\mathrm{SiO}_{2}, 11,22 \%$ de $\mathrm{Al}_{2} \mathrm{O}_{3}, 8,40 \%$ de $\mathrm{MgO}, 0,49$ de $\mathrm{Fe}_{2} \mathrm{O}_{3}$ y $0,71 \%$ de $\mathrm{S}^{2-}$. Era una escoria básica $\left(\mathrm{F}_{3}=\left(\mathrm{CaO}+\mathrm{MgO}+\mathrm{Al}_{2} \mathrm{O}_{3}\right) / \mathrm{SiO}_{2}\right)$ $=1,72$ ). La superficie específica de trabajo fue de 4.480 $\mathrm{cm}^{2} / \mathrm{g}$.

La composición de las disoluciones alcalinas utilizadas en dicho trabajo se presentan en la Tabla I. Estas disoluciones se prepararon con una mezcla de waterglass comercial $\left(28,01 \%\right.$ de $\mathrm{SiO}_{2}, 8,53 \%$ de $\mathrm{Na}_{2} \mathrm{O}, 62,99 \%$ de $\mathrm{H}_{2} \mathrm{O}$ ), $\mathrm{NaOH}$ y $\mathrm{H}_{2} \mathrm{O}$ desionizada y descarbonatada. En todos los casos se mantuvo constante el módulo $\mathrm{SiO}_{2}$ / $\mathrm{Na}_{2} \mathrm{O}=1,5$ y se varió la concentración de $\mathrm{Na}_{2} \mathrm{O}(3,4$ y 5 $\%$ en peso con respecto de la escoria). La relación disolución activadora/escoria fue constante e igual a 0,4 .

\section{EXPERIMENTAL}

A blast furnace slag from Avilés (Spain) was used. Its composition was $42,80 \%$ of ( $\mathrm{CaO}, 36,10 \%$ of $\mathrm{SiO}, 11.22$ $\%$ of $\mathrm{Al}_{2} \mathrm{O}_{3}, 8,40 \%$ of $\mathrm{MgO}, 0.49$ of $\mathrm{Fe}_{2} \mathrm{O}_{3}$ and $0.71 \%$ of $\mathrm{S}^{2-}$. It was a basic slag $\left.\left.\left(\mathrm{F}_{3}-(\mathrm{CaO} \cdot \mathrm{MgO}) \cdot \mathrm{Al} 2 \mathrm{O}_{3}\right) . \mathrm{SiO}\right)_{2}\right)$ 1.72). The especific surface was $4.480 \mathrm{~cm}^{2} \mathrm{~g}$.

Alkaline activators composition is shown in Table I. These solutions were prepared with a mixture of commercial waterglass $\left(28.01 \% \mathrm{SiO}_{2}, 8.53 \% \mathrm{Na}_{2} \mathrm{O}, 62.99 \% \mathrm{H}_{2} \mathrm{O}\right)$. $\mathrm{NaOH}$ and deionised and decarbonated water. In all cases. $\mathrm{Si}{ }_{2} \mathrm{O} / \mathrm{Na}_{2} \mathrm{O}$ ratio was maintained constant and equal to 1.5 and $\mathrm{Na}_{2} \mathrm{O}$ concentration was varied $(3.4$ and $5 \%$ wt. to the slag). The activator solution/slag ratio was constant and equal to 0.4 .

\section{TABLA I (TABLE /)}

Composición de la disolución alcalina activante (Composition of the alkaline activator solution)

\begin{tabular}{||c|c|c|c|c|c||}
\hline $\begin{array}{c}\mathrm{Na},=\% \text { en } \\
\text { peso } \\
(\mathrm{Na}, \mathrm{O} \% \mathrm{wt})\end{array}$ & Waterglass \% & $\mathrm{NaOH} \%$ & $\mathrm{H}, \mathrm{O} \%$ & $\mathrm{pH}$ & $\begin{array}{c}\text { Dend. Mezc. } \\
\text { (Mixt. Dend.) } \\
\mathrm{gr} / \mathrm{cm}^{3} .\end{array}$ \\
\hline 3 & 40,16 & 5,25 & 54,59 & 13,20 & 1,19 \\
\hline 4 & 53,55 & 7,09 & 39,36 & 13,22 & 1,27 \\
\hline 5 & 66,94 & 8,76 & 24,3 & 13,23 & 1,35 \\
\hline
\end{tabular}

Las mezclas disolución activante/escoria fueron estudiadas por calorimetría de conducción isotérmica a las siguientes temperaturas de trabajo: $25,35,45 \mathrm{y}$ $60{ }^{\circ} \mathrm{C}$. El tiempo de ensayo fue variable hasta alcanzar una velocidad de evolución de calor igual o inferior a $0,3 \mathrm{~kJ} / \mathrm{kg} \cdot \mathrm{h}$

Por calorimetría de conducción isotérmica se obtuvieron valores de calor de hidratación, así como de la velocidad de evolución del calor en función del tiempo. A partir de estos datos se determinó el grado de reacción $(\alpha)(6-8)$ o de avance de la reacción.

\section{RESULTADOS}

\subsection{Velocidad de hidratación}

En las Figs. 1, 2 y 3 se muestran las curvas de velocidad de evolución de calor de hidratación de la escoria $(\mathrm{kJ} / \mathrm{kg} \cdot \mathrm{h}$ ) versus tiempo (horas) para las concentraciones de 3,4 y $5 \%$ en peso de $\mathrm{Na}_{2} \mathrm{O}$, para las distintas temperaturas de ensayo.
The mixtures activator solution slag were studied by isothermal conduction calorimetry at the following working temperatures: $25,35,45$ and $60^{\circ} \mathrm{C}$.' T'est time was variable until a rate heat evolution reached was equal or inferior to $0.3 \mathrm{~kJ} / \mathrm{kg} \cdot \mathrm{h}$

By means of isothermal conduction calorimetry: hydration heat values were obtained likewise the rate of heat evolution as a function of time. From these data. reaction degree. $(\alpha)(6-8)$ was determined.

\section{RESULTS}

\subsection{Hydration rate}

In Figs. 1, 2 and 3, rate of heat evolution of the slag versus time (hours) is shown for concentrations 3.7 and $5 \%$ wt. of $\mathrm{Na}_{2} \mathrm{O}$ for the different test temperatures. 


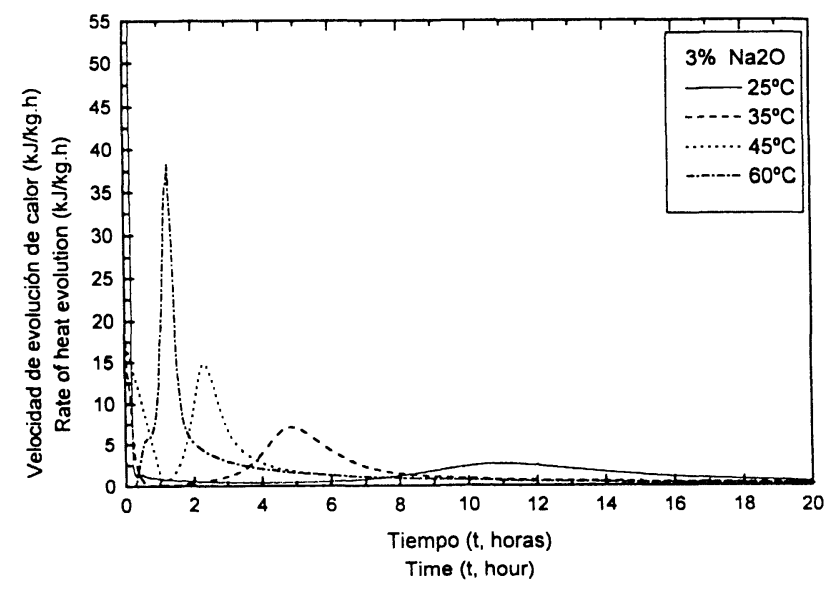

Fig. 1.- Velocidad de evolución de calor ( $3 \%$ en peso de $\mathrm{Na}_{2} \mathrm{O}$ ). Fig. 1.- Rate of heat evolution $\left(3 \% w t . \mathrm{Na}_{2} \mathrm{O}\right)$

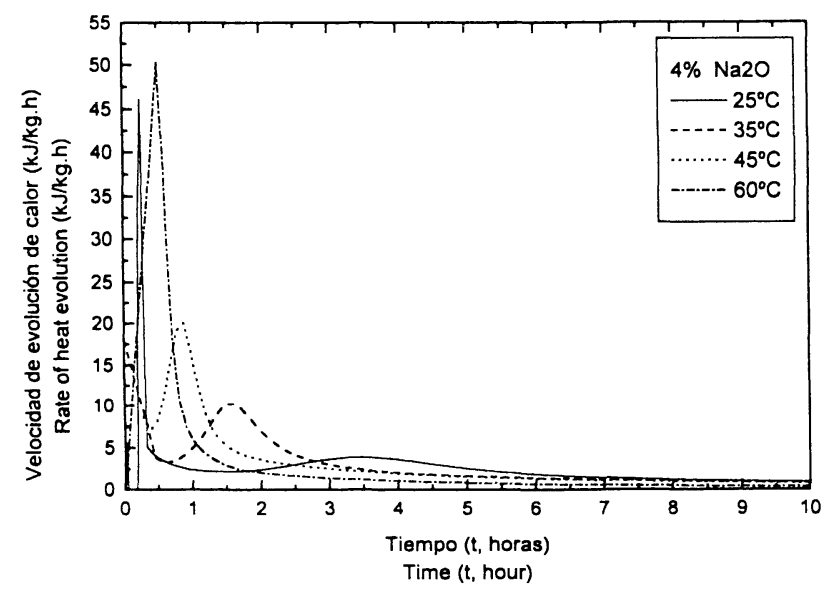

Fig. 2.- Velocidad de evolución de calor ( $4 \%$ en peso de $\left.\mathrm{Na}_{2} \mathrm{O}\right)$.

Fig. 2.- Rate of heat evolution $\left(4 \%\right.$ wt. $\left.\mathrm{Na}_{2} \mathrm{O}\right)$

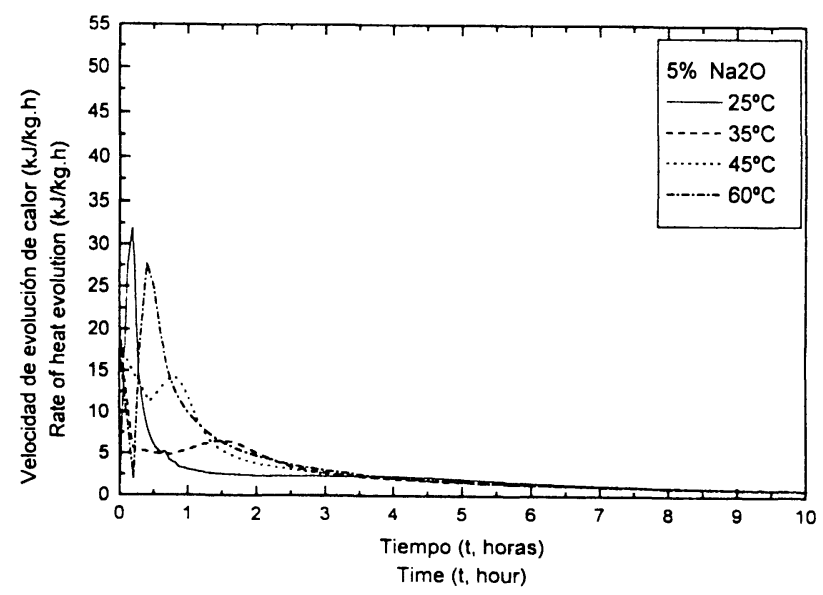

Fig. 3.- Velocidad de evolución de calor $\left(5 \%\right.$ en peso de $\left.\mathrm{Na}_{2} \mathrm{O}\right)$.

Fig. 3.- Rate of heat evolution ( $5 \%$ wt. $\left.\mathrm{Na}_{2} \mathrm{O}\right)$

El primer pico de las curvas de velocidad de evolución de calor asociado a la disolución parcial de la escoria únicamente es detectado a $25^{\circ} \mathrm{C}$. Según aumenta la temperatura, las velocidades de las reacciones se incrementan. Esto se manifiesta en las curvas calorimétricas, ya que el primer pico no se observa, el período de inducción se acorta y la señal del segundo pico aparece con mayor intensidad y a tiempos más cortos. Este efecto es más acusado cuando las temperaturas del proceso son 45 y $60{ }^{\circ} \mathrm{C}$.

En las Figs. 1 y 2 se observa cómo al aumentar la concentración de la disolución activante, de un 3 a un $4 \%$ en peso de $\mathrm{Na}_{2} \mathrm{O}$, disminuye el período de inducción y aumentan las intensidades del segundo pico. Sin embargo, al aumentar la concentración a un $5 \%$ en peso de $\mathrm{Na}_{2} \mathrm{O}$, Fig 3, la señal del segundo pico aparece a tiempos prácticamente iguales a los obtenidos al activar con un $4 \%$ en peso de $\mathrm{Na}_{2} \mathrm{O}$, pero con menores intensidades. Obteniéndose, en algunos casos, intensidades menores incluso que al activar con un $3 \%$ en peso de $\mathrm{Na}_{2} \mathrm{O}$.
The first peak of rate of heat evolution curves, associated to partial slag dissolution is only detected when test temperature is $25^{\circ} \mathrm{C}$. As temperature increases, reaction rates are increased. This is shown in calorimetric curves, because the first peak is not observed, induction period is shortened and the signal of the second peak is more intense and it appears at shorter times. This effect is more acute when temperatures are 45 and $60^{\circ} \mathrm{C}$.

In Figs. 1 and 2 the shorter induction period and the higher intensity of the second peak as concentration increases are observed. However, as concentration to a $5 \%$ wt. of $\mathrm{Na}_{3} \mathrm{O}$ (Fig. 3), the signal of the second peak appears at practically similar times to those obtained when the activation is carried out with $4 \%$ wt. of $\mathrm{Na}_{2} \mathrm{O}$, but the intensities are lower. These intensities are even lower that those obtained when the activation is carried out with $3 \%$ wt. of $\mathrm{Na}_{2} \mathrm{O}$. 
En la Tabla II aparecen los valores numéricos obtenidos para la velocidad del segundo pico, así como el tiempo en el cual dicha señal aparece.

\subsection{Calor de hidratación}

En las Figs. 4, 5 y 6 se representa $Q^{\prime}\left(t^{\prime}\right)(\mathrm{kJ} / \mathrm{kg})$ versus $t^{\prime}$ (h). Donde $Q^{\prime}\left(t^{\prime}\right)$ es calor liberado a partir del inicio
In Table II, the numerical values obtained for second peak rate and the time at which this signal appears are shown.

\subsection{Hydration heat}

In Figs. 4, 5 and $6 Q^{\prime}\left(t^{\prime}\right)(\mathrm{kJ} / \mathrm{kg})$ is represented versus $t^{\prime}(h)$. Where $Q^{\prime}\left(t^{\prime}\right)$ is the heat released from the

\section{TABLA II (TABLE /I)}

Velocidad de evolución de calor del segundo pico y tiempo (Rate of heat evolution in the second peak and time at which it appears)

\begin{tabular}{|c|c|c|c|c|c|c|}
\hline \multirow{3}{*}{$\begin{array}{c}\text { Temperatura } \\
\text { (Temperature) } \\
\left({ }^{\circ} \mathrm{C}\right)\end{array}$} & \multicolumn{6}{|c|}{ Concentraciones $\left(\%\right.$ en peso de $\mathrm{Na}_{2} \mathrm{O}$ ) (Concentrations (\% wt of $\left.\mathrm{Na}_{2} \mathrm{O}\right)$ ) } \\
\hline & \multicolumn{2}{|c|}{$3 \%$} & \multicolumn{2}{|c|}{$4 \%$} & \multicolumn{2}{|c|}{$5 \%$} \\
\hline & $V_{,(k, J / k y \cdot h)}$ & t. (h.) & $V_{,(k \cdot J / k g \cdot h)}$ & t. (1h.) & $V_{2}(\mathrm{k} . J / \mathrm{kg} \cdot \mathrm{h})$ & t. (h.) \\
\hline 25 & 2,68 & 11,13 & 3,96 & 3,45 & 2,44 & 3,75 \\
\hline 35 & 7,18 & 4,87 & 10,34 & 1,54 & 6,58 & 1,44 \\
\hline 45 & 14,71 & 2,37 & 20,12 & 0,87 & 14,27 & 0,84 \\
\hline 60 & 38,40 & 1,27 & 50,45 & 0,5 & 27,69 & 0,4 \\
\hline
\end{tabular}

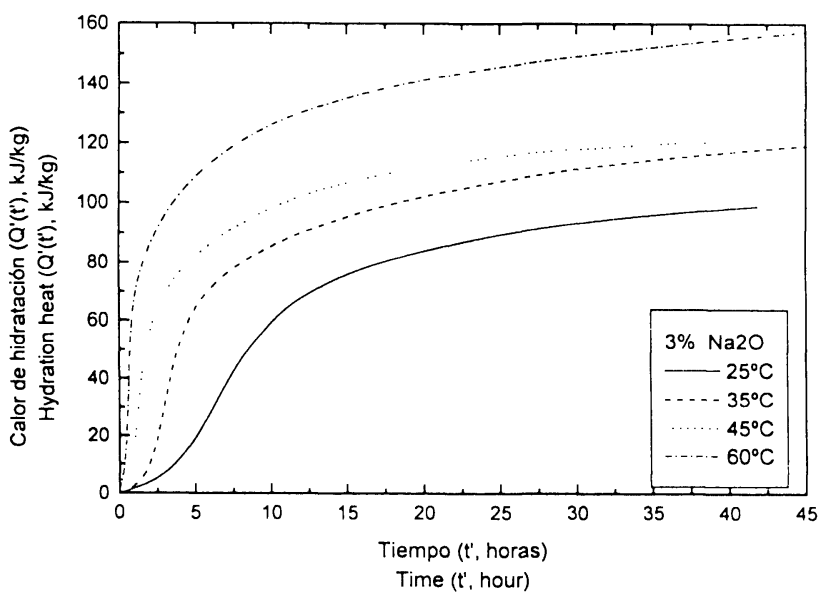

lïg. 4.- Calor de hidratación ( $3 \%$ en peso de $\left.\mathrm{Na}_{2}()\right)$. Fig. 4.- Ifydration heat $\left(3 \%\right.$ wt. $\left.\mathrm{Na}_{2}()\right)$.

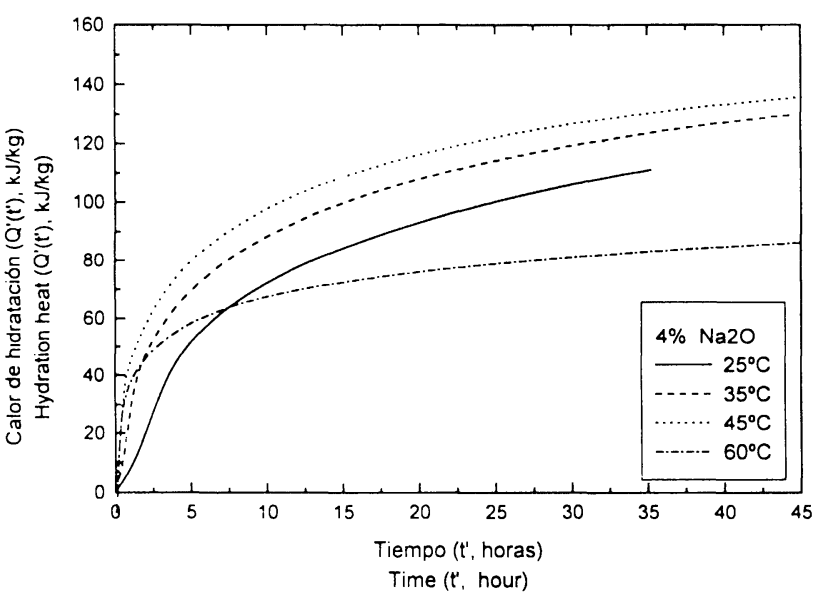

Iig. 5.- Calor de hidrat ación ( $4 \%$ en peso de $\mathrm{Na},()$ ). Fig. 5. - Hydration heat (4\% $\mathrm{wt} . \mathrm{Va}(\mathrm{O})$.

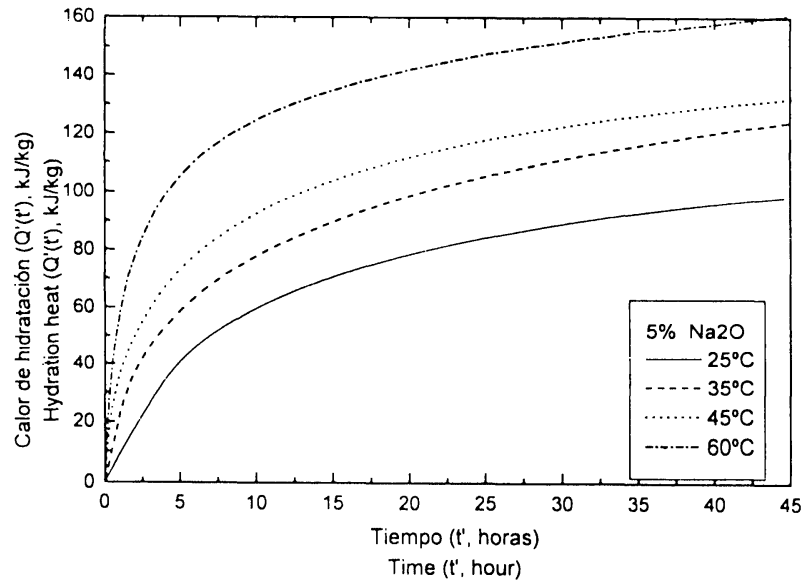

Iig. 6.- Calor de hidratación ( $5 \%$ en peso de $\mathrm{Na}_{2}()$ ).

lïg. 6.- Hydration heat (5\% wt. $\left.\mathrm{Na}_{2}()\right)$. 
del segundo pico de las curvas de velocidad de evolución de calor y $t^{\prime}=t-t_{p}$, siendo $t_{p}$ el tiempo al cual se tomaron los valores de $Q^{\prime}\left(t^{\prime}\right)$.

Se observa cómo, según aumenta la temperatura, aumentan los valores de Q'( $\mathrm{t}^{\prime}$ ), a excepción de la curva correspondiente a la escoria activada con un $4 \%$ en peso de $\mathrm{Na}_{2} \mathrm{O}$ a $60^{\circ} \mathrm{C}$ (Fig 5). Esto se justifica, ya que la reacción a $60^{\circ} \mathrm{C}$ es tan rápida que parte del calor liberado en el proceso no pudo ser registrado.

$\mathrm{Al}$ variar la concentración de la disolución activante los valores más altos de $Q^{\prime}\left(t^{\prime}\right)$ se obtienen con un $4 \%$ en peso de $\mathrm{Na}_{2} \mathrm{O}$, a excepción de la curva activada a $60^{\circ} \mathrm{C}$, como ya se ha indicado anteriormente.

\subsection{Grado de reacción}

En las Figs. 7, 8 y 9 se representa el grado de avance de la reacción $(\alpha)$, obtenido según la ecuación [1] (7), versus t'. Se observa cómo para las tres concentraciones estudiadas al aumentar la temperatura, disminuye el tiempo necesario para alcanzar el grado máximo de

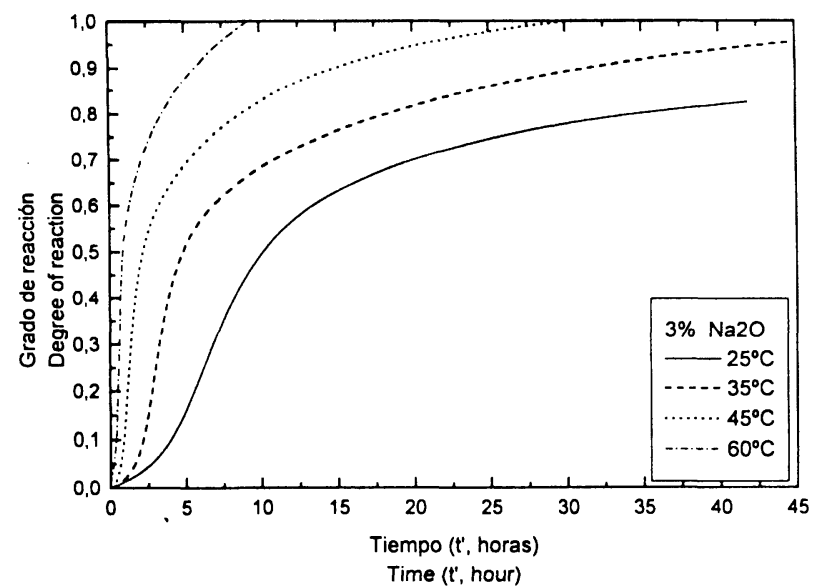

Fig 7.- Grado de reacción ( $3 \%$ en peso de $\mathrm{Na}_{2} \mathrm{O}$ ). Fig. 7.- Degree of reaction (3\%wt. $\left.\mathrm{Na}_{2} \mathrm{O}\right)$. beginning of the second peak of the rate of heat evolution curves and $t^{\prime}=t$-tp being tp the time at which values of $Q^{\prime}\left(t^{\prime}\right)$ were taken.

As temperature increases, $Q^{\prime}\left(t^{\prime}\right)$ values increase except for the curve corresponding to the slag activated with $4 \%$ wt. of $\mathrm{Na}_{2} \mathrm{O}$ at $60^{\circ} \mathrm{C}$. (Fig. 5). This is explained by the fast reaction at $60^{\circ} \mathrm{C}$ that make impossible to register a part of the heat released.

When concentration of activator solution is varied, the higher $Q^{\prime}\left(t^{\prime}\right)$ values are obtained with a $4 \%$ wt. of $\mathrm{Na}_{2} \mathrm{O}$, except for the curve at $60^{\circ} \mathrm{C}$, as it has been mentioned before.

\subsection{Reaction degree}

In figure 7, 8 and 9 , reaction degree $(\alpha)$ (obtained according to equation [1] [7]) is represented versus $t$ '. It is observed how for the three concentrations studied, the time necessary for reaching the maximum reaction

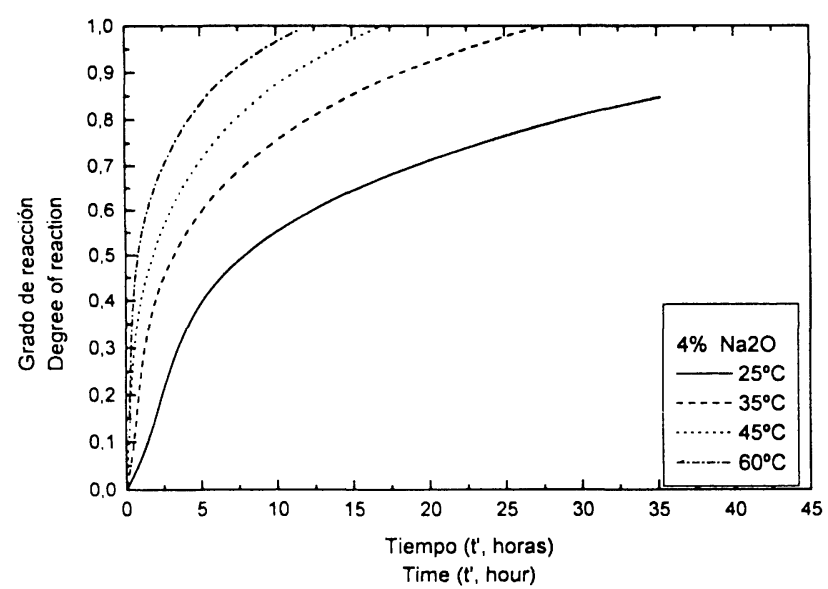

Fig. 8.- Grado de reacción ( $4 \%$ peso de $\mathrm{Na}_{2} \mathrm{O}$ ).

Fig. 8.- Degree of reaction ( $4 \%$ wt. $\mathrm{Na}_{2} \mathrm{O}$ ).

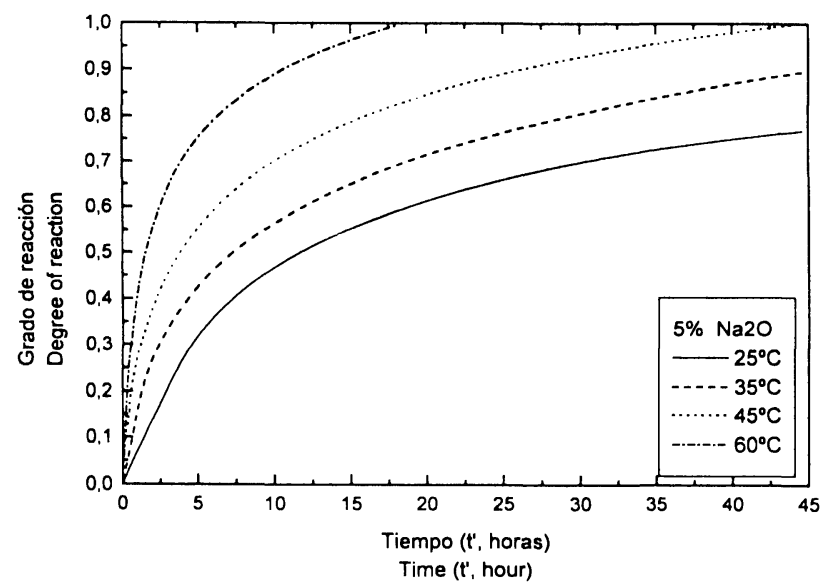

Fig. 9.- Grado de reacción ( $5 \%$ en peso de $\mathrm{Na}_{2} \mathrm{O}$ ).

Fig. 9.- Degree of reaction ( $5 \%$ wt. $\mathrm{Na}_{2} \mathrm{O}$ ). 
reacción. También, en este caso, es la escoria activada con un $4 \%$ en peso de $\mathrm{Na}_{2} \mathrm{O}$ la que da lugar a los tiempos de reacción más cortos.

Es necesario indicar que estos valores del grado de reacción, $\alpha$, se han obtenido a partir de datos calorimétricos utilizando las ecuaciones [ 1 y 2 ], es decir, considerando unos valores de calor máximo (Q'max) para velocidades de calor igual o menor de 0,3 $\mathrm{kJ} / \mathrm{kg} \cdot \mathrm{h}$. Sin embargo, estos valores de $\alpha$, no tienen por que coincidir, y de hecho no lo hacen, con los valores de $\alpha$ obtenidos por otros métodos, por ejemplo con el método de extracción con metanol-ácido salicílico (9).

\subsection{Grado de reacción versus $t^{\prime} / t^{\prime}{ }_{0,5}$}

En las Figs. 10, 11 y 12 se representa el grado de reacción $(\alpha)$ versus $t^{\prime} / t^{\prime}{ }_{0.5}$. Donde $t^{\prime}{ }_{0,5}$ es el tiempo necesario para alcanzar el $50 \%$ de la reacción, es decir $\alpha=0,5$.

Como se desprende de las Figs. 11 y 12 , las curvas obtenidas a las distintas temperaturas coinciden. Esto

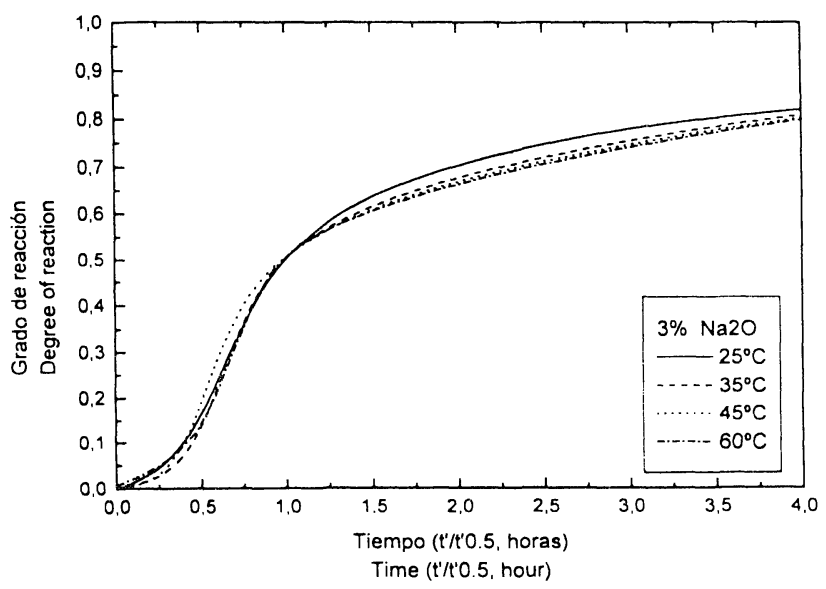

Fig. 10.- (rrado de reacción versus $\mathrm{t}^{\prime} \mathrm{t}^{\prime}{ }_{0,5}\left(3 \%\right.$ en peso de $\left.\mathrm{Na}_{2}()\right)$. Fig. 10.- Degree of reaction $t^{\prime} t^{\prime}{ }_{0.5}\left(3 \%\right.$ wt. $\mathrm{Na}_{2}(\mathrm{O})$. degree decreases when temperature increases. Also in this case the slag activated with $4 \%$ wt. of $\mathrm{Na}_{2} \mathrm{O}$ is that giving reaction times shortest.

It is worth indicating that these reaction degree values. $\alpha$, have been obtained from calorimetric data using equations [1] and [2], this is, considering maximum heat values $Q$ '(max) for rate values equal or lower than $0.3 \mathrm{~kJ} \mathrm{~kg} \cdot \mathrm{h}$. However, these values of $\alpha$. do not have to coincide, and they don 't, to other values of reaction degree obtained by other methods. Fior example, those obtained by methanol-salicylic acid method (9).

\subsection{Reaction degree versus $t^{\prime} / t^{\prime}$}

In Figs. 10, 11 and 12 the reaction degree $(\alpha)$ is represented versus $t^{\prime} t^{\prime}$ '. Where $t^{\prime}$ '. is the time necessary for the $50 \%$ of reaction to be reached. this is $\alpha \quad 0.5$.

As it is seen from ligs. 11 and 12, the curves obtained at the different temperatures are similar. This is

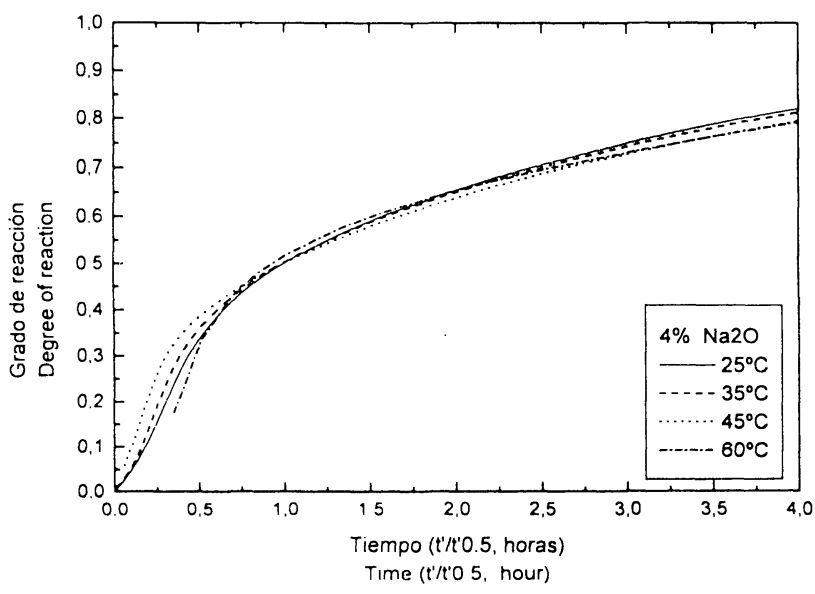

Fig. 11.- (irado de reacción versus t't $t^{\prime}{ }_{1.5}\left(4 \%\right.$ en peso de $\left.\mathrm{Na}_{2}()\right)$. Hig. 11.- I)egree of reaction $t^{\prime} t^{\prime}{ }_{05}(4 \% \mathrm{wt} . \mathrm{Na}(0)$.

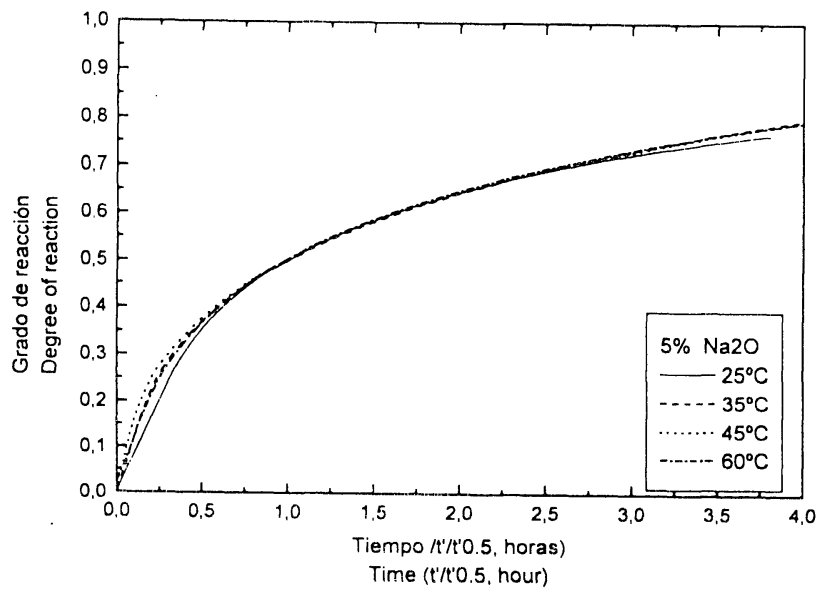

Fig. 12.- (irado de reacción versus t't't ${ }_{0.5}^{\prime}\left(5 \%\right.$ en peso de $\left.\mathrm{Na}_{2}()\right)$.

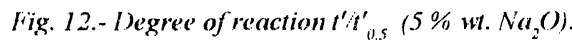


está indicando que el proceso de activación de la escoria para $\alpha>0,5$ y para las concentraciones de 4 y $5 \%$ en peso de $\mathrm{Na}_{2} \mathrm{O}$, transcurre a través de un mismo mecanismo.

En la Fig 10 (escoria activada con un $3 \%$ en peso de $\mathrm{Na}_{2} \mathrm{O}$ ) se observa cómo la curva obtenida a $25^{\circ} \mathrm{C}$ presenta una forma distinta a las evidenciadas a 35, 45 y $60{ }^{\circ} \mathrm{C}$. No obstante, las curvas obtenidas a estas últimas temperaturas coinciden con las obtenidas al activar con 4 y $5 \%$ en peso de $\mathrm{Na}_{2} \mathrm{O}$.

\section{DISCUSIÓN}

A partir de los datos calorimetricos obtenidos se deduce que, en las condiciones de estudio, el $4 \%$ en peso de $\mathrm{Na}_{2} \mathrm{O}$, en la concentración de la disolución activadora, parece ser un valor umbral. Concentraciones superiores no inducen modificaciones significativas.

La temperatura de reaccion tiene una influencia marcada en la velocidad del proceso, al aumentar la temperatura se incrementan, de modo notable, las velocidades de las reacciones.

\section{EL MECANISMO QUE CONTROLA EL PROCESO DE ACTIVACIÓN}

Teniendo en cuenta los resultados de las Figuras 10, 11 y 12 , en las que las curvas para valores de $\alpha>0,5$ prácticamente coinciden (a excepción de la curva correspondiente a la escoria activada con un $3 \%$ de $\mathrm{Na}_{2} \mathrm{O}$, a $25^{\circ} \mathrm{C}$ ), se puede decir que el mecanismo que controla los procesos de reacción va a ser, en los tres casos, el mismo.

Comparando estas curvas con las descritas por Sharp et al. (10), se deduce que las mismas corresponden a procesos gobernados por difusión. El proceso de activación de la escoria transcurre, a partir del período de inducción, en su mayor parte por difusión. Esta difusión ocurre a través de una capa de productos de reacción que recubren el grano de escoria que aún permanece anhidro. La ecuación que mejor explica este proceso de difusión es la ecuación de Jander (11) [3], es decir.

Ecuación de Jander: indicating that the slag activation process for $\alpha>0.5$ and for $4 \%$ and $5 \%$ wt. of $\mathrm{Na}_{2} \mathrm{O}$ concentrations, goes through the same mechanism.

In Fig. 10 (activated slag with $3 \%$ of $\mathrm{Na2O}$ ) it can be observed how the curve obtained at $25^{\circ} \mathrm{C}$ has a different shape to those evidenced at 35,45 and $60^{\circ} \mathrm{C}$. However, curves obtained at these temperaturescoincide with those obtained when activating with 4 and $5 \%$ wt.

\section{DISCUSSION}

From calorimetric data obtained, it is deduced that, in the conditions of the study, $4 \%$ wt. of $\mathrm{Na}_{2} \mathrm{O}$ seems to be a threshold values. Higher concentrations do not lead to significative variations.

The temperature of the process has a great influence in the rate of the process, as temperature increases reaction rates increase considerably.

\section{THE MECHANISM CONTROLLING THE ACTIVATION PROCESS}

Taking into account the results of the Figs. 10,11 and 12. in which the curves coincide for values of $\alpha>0.5$ (except for the curve corresponding to the activation with $3 \%$ of $\mathrm{Na}_{2}\left(\mathrm{O}\right.$, at $\left.25^{\circ} \mathrm{C}\right)$, it can be said that the mechanism controlling reaction processes is the same in the three cases.

Comparing these curves with those described by Sharp et al. (10), it can be deduced that they correspond to diffusion processes. The process of slag activation goes mostly through diffusion from the induction period. This diffusion occurs through a reaction products layer that surrounds the anhydrous slag grain. The equation that better explains this diffusion process is that of Jander (11) [3]:

Jander equation

$$
D_{3}=\left(1-(1-\alpha)^{1 / 3}\right)^{2}=\left(k / r^{2}\right) t=0,0426\left(t / t_{0,5}\right)
$$

$\alpha=$ grado de reacción; $\mathrm{K}=$ constante; $\mathrm{r}=$ radio de las partículas; $\mathrm{t}_{0,5}=$ tiempo necesario para que $\alpha=0,5$.

En la Tabla III aparecen los resultados obtenidos al aplicar la ecuación de Jander a los datos $\alpha=$ reaction degree; $K=$ constant $; r=$ particle radius; $t_{0.5}=$ time necessary for $\alpha=0.5$.

In Table III the results obtained when applying Jander equation to experimental data appear. Where $K^{\prime}$ ' 
experimentales. Donde $\mathrm{K}^{\prime}\left(\mathrm{K}^{\prime}=\mathrm{K} / \mathrm{r}^{2}\right)$, es la constante de velocidad, que se obtiene al aplicar la ecuación [3] a los datos experimentales representados en las Figs. 7, 8 y 9. Mientras que $\mathrm{m}$, es el valor de la pendiente de las recta que se obtiene al aplicar la ecuación [3] a los datos experimentales de las Figs. 10, 11 y 12. E1 valor teórico de $\mathrm{m}$, que indica que el proceso transcurre por difusión, es de 0,0426 .

Esta ecuación de Jander es válida cuando la relación entre el espesor de la capa de los productos de hidratación formados y el radio de las partículas iniciales ( $r$ ) es menor que 0,5 , lo cual implica un grado bajo de conversión de las partículas iniciales (12).

Se realizaron estudios mediante el método de extracción con metanol-ácido salicílico (9).

Comprobándose, a las edades de estudio, que los grados de reacción reales de la escoria eran bajos, permaneciendo sin reaccionar una alta proporción de escoria anhidra.
$\left(K^{\prime}=k / r^{2}\right)$ is the rate constant obtained when applying equation / $3 /$ to experimental data represented in Figs. 7.8 and 9. While $m$ is the slope value obtained when equation (3/ is applied to experimental data of the figures 10, 11 and 12. The theoretical value of $m$ indicating that the process occurs through diffusion is 0.0426 .

This Jander equation is valid when relation among the width of hydration products layer and the radii of the initial particles ( $r$ ) is lower than 0.5. involving a low conversion degree of the initial particles (12).

Studies were carried out through the methanolsalicylic method (9). At the ages studied, the real reaction degrees of the slag were low and a high proportion of anhydrous slag remained unreacted.

TABLA III (TABLE III)

Resultados al aplicar la ecuación de Jander [3]

(Results obtained when Jander equation is applied [3])

\begin{tabular}{||c|c|c|c|c|c|c||}
\hline \multirow{2}{*}{$\begin{array}{c}\text { Temperara } \\
(\text { Temperature) } \\
\left({ }^{\circ} \mathrm{C}\right)\end{array}$} & \multicolumn{2}{|c|}{ Concentración (\% en peso de $\mathrm{Na}_{2} \mathrm{O}$ ) /Concentration (\% wt of $\mathrm{Na}_{2} \mathrm{O}$ ) } \\
\cline { 2 - 7 } & \multicolumn{2}{|c|}{$3 \%$} & \multicolumn{2}{|c|}{$4 \%$} & \multicolumn{2}{c|}{$5 \%$} \\
\hline 25 & $\mathrm{~K}^{\prime}$ & $\mathrm{m}$ & $\mathrm{K}^{\prime}$ & $\mathrm{m}$ & $\mathrm{K}^{\prime}$ & $\mathrm{m}$ \\
\hline 35 & 0,00899 & 0,043599 & 0,014992 & 0,049703 & 0,006016 & 0,04430 \\
\hline 45 & 0,019065 & 0,042411 & 0,024741 & 0,044986 & 0,011152 & 0,042928 \\
\hline 60 & 0,052499 & 0,045342 & 0,075557 & 0,044051 & 0,028369 & 0,044194 \\
\hline \hline
\end{tabular}

\section{LA ENERGÍA DE ACTIVACIÓN}

Aplicando la ecuación $\mathrm{D}_{3}(\alpha)=\mathrm{K}$ 't, se determinaron los valores de las constantes de velocidad $\left(K^{\prime}=K / r^{2}\right)$ a las distintas temperaturas de estudio. Estos valores numéricos aparecen el la Tabla III. Una vez conocidos los valores de la constante de velocidad, se aplicó la ecuación de Arrhenius [4] para determinar la energía de activación de la escoria a partir del periodo de inducción.

\section{THE ACTIVATION ENERCIY}

Applying the equation $I_{3}(\alpha) \cdot K t$, the rate constants values were determined $\left(K^{-\cdots} k^{\prime} r^{2}\right)$ at the different temperatures of study. The values obtained appear in Table III. Once the rate constant values are known. Arrhenius equation was applied /4/ to determine the activation energy of the slag activation after the induction period.

$$
\mathrm{K}=\mathrm{K}_{0} \exp (-\mathrm{AE} \mathrm{a} / \mathrm{RT})
$$

En la Fig. 13 se muestran las rectas obtenidas: a) $3 \%$ $\mathrm{Na}_{2} \mathrm{O}$; b) $4 \% \mathrm{Na}_{2} \mathrm{O}$ y c) $5 \% \mathrm{Na}_{2} \mathrm{O}$, al aplicar dicha ecuación [4]. De la pendiente de la recta obtenida se obtuvo el valor de la energía de activación ( ver Tabla IV).
Applying this equation /4/, the obtained line appear in Fig. 13: a) $3 \% \mathrm{Na}_{2} \mathrm{O}$; b) $4 \% \mathrm{Na}_{2} \mathrm{O}$ and c) $\left.5 \% \mathrm{Na} a_{2} \mathrm{O}\right)$. The linear relationship propose the energy activaton (see Tabla IV). 


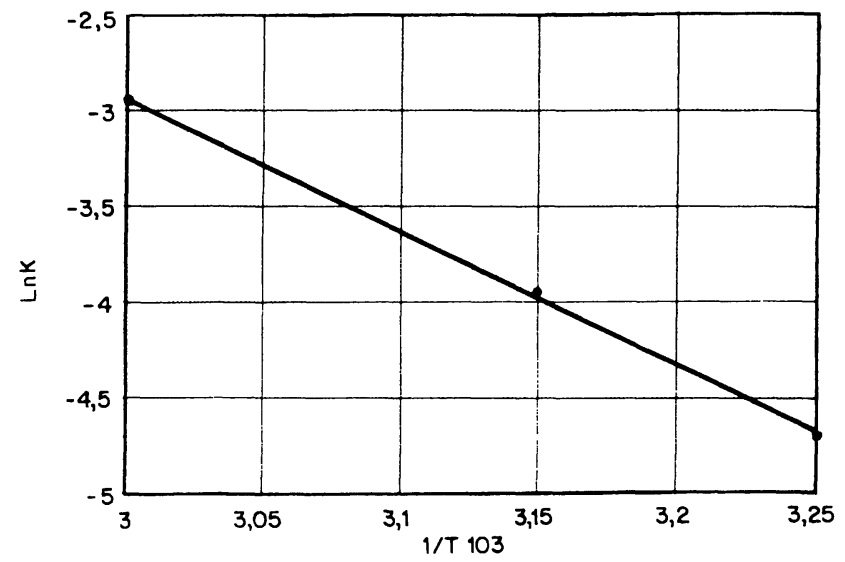

(a)

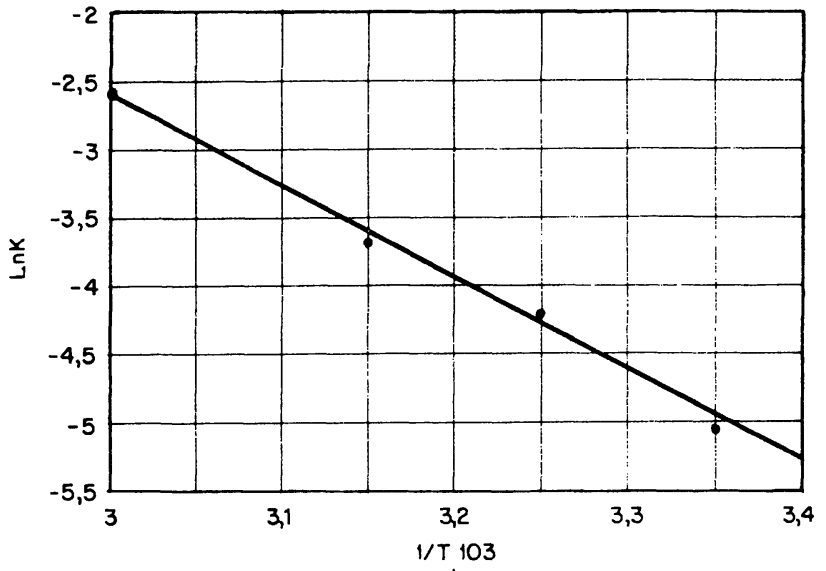

(b)

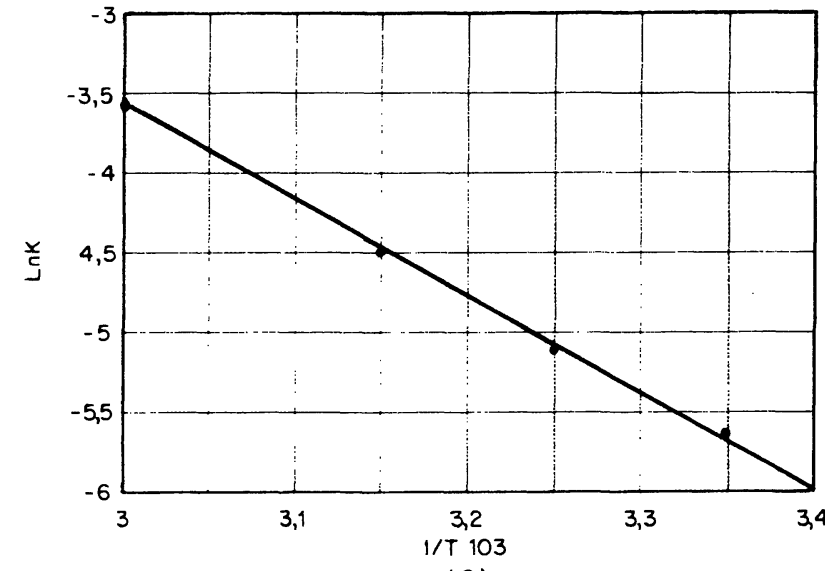

(C)

Fig. 13.- Energía de activación: a) $3 \% \mathrm{Na}_{2}\left(\mathrm{O} ;\right.$ b) $4 \% \mathrm{Na}_{2}()$; c) $5 \% \mathrm{Na}_{2} \mathrm{O}$

Fig. 13.- Activation energy : a) $3 \% \mathrm{Na}_{2} \mathrm{O} ;$ b) $4 \% \mathrm{Na}_{2} \mathrm{O} ;$ c) $5 \% \mathrm{Na}_{2} \mathrm{O}$

TABLA IV (TABLE IV)

Energía de activación

(Activation energy)

\begin{tabular}{||c|c|c|c|}
\hline \multirow{2}{*}{$\begin{array}{c}\text { Energía de activación } \\
\text { (Activation energy) } \\
(\mathrm{kJ} / \mathrm{mol})\end{array}$} & \multicolumn{3}{|c|}{ Concentración (\% en peso de $\mathrm{Na}_{2} \mathrm{O}$ ) (Concentration $\left(\%\right.$ wt of $\left.\mathrm{Na}_{2} \mathrm{O}\right)$} \\
\cline { 2 - 4 } & $3 \%$ & $4 \%$ & $5 \%$ \\
\cline { 2 - 4 } & 58,33 & 57,3 & 50 \\
\hline
\end{tabular}

$\mathrm{El}$ valor de $\mathrm{AE}^{\mathrm{a}}$, obtenido después del período de inducción (Tabla IV), para una escoria molida de alto horno, activada alcalinamente con $\mathrm{Na}_{2} \mathrm{SiO}_{3}+\mathrm{NaOH}$ a distintas concentraciones $(3,4$ y $5 \%$ en peso de $\mathrm{Na}_{2} \mathrm{O}$ ), es del mismo orden que el obtenido por otros métodos por otros autores (13-15).

\section{CONCLUSIONES}

Las principales conclusiones que se pueden extraer del presente trabajo son:
V'alues obtained after the induction period (Table IV) for a grounded blast furnace slag alkaline activated with different concentrations $(3,4$ and $5 \%$ wt.) is of the same order to that obtained by other authors using other methods.

\section{CONCLUSIONS}

The main conclusions of this work are: 
a) En mezclas de la disolución activadora ( $w g+\mathrm{NaOH})$, la concentración de un $4 \%$ en peso de $\mathrm{Na}_{2} \mathrm{O}$ parece ser un valor umbral.

b) El mecanismo que controla el proceso de activación alcalina de una escoria granulada de alto horno, cuando el activador es una mezcla de $\mathrm{Na}_{2} \mathrm{SiO}_{3}$ y $\mathrm{NaOH}$, después del período de inducción y para valores de $\alpha>$ 0,5 , es la difusión.

c) El proceso de difusión sigue la ecuación de Jander $\left(D_{3}=\left(1-(1-\alpha)^{1 / 3}\right)^{2}=\left(k / r^{2}\right) t=0,0426\left(t / t_{0.5}\right)\right)$. Esto indica grados bajos de hidratación real de las partículas a las edades de estudio (45 horas).

d) La energía de activación de la escoria no varía prácticamente con la concentración de la disolución activante. Su valor es del orden de un $50-58 \mathrm{~kJ} / \mathrm{mol}$.

\section{AGRADECIMIENTOS}

Las autoras del presente trabajo desean mostrar su agradecimiento a la Subdirección General de Promoción de la Investigación por la subvención concedida a través del Programa Sectorial de Promoción del Conocimiento (PB94-0048). a) In mixtures of the activator solution ( $\mathrm{wg}+\mathrm{NaOH}$ ), 4 $\%$ wt. of $\mathrm{Na}_{2} \mathrm{O}$ concentration seems to be a threshold value.

b) The mechanism controlling the process of the activation of a blast furnace slag when the activator is a mixture of $\mathrm{Na}_{2} \mathrm{SiO}_{3}+\mathrm{NaOH}$ after the induction period for values of $\alpha>0.5$, is diffusion.

c) Diffusion process follows Jander equation. This indicates low real hydration degrees of the particles at the test times (45 hours).

d) Activation energy of the slag does not vary practically with the activator solution concentration. Its value is of $50-58 \mathrm{~kJ} / \mathrm{mol}$

\section{ACKNOWLEDGEMENTS}

The authors of the present work want to acknowledge to Subdirección General de Promoción de la Investigacion for funding this research through Programa Sectorial de Promoción General del Conocimiento (PB94-0048).

\section{BIBLIOGRAFIIA}

(1) F. PUERTAS: “Cementos de escorias activadas alcalinamente: Situación actual y perspectivas de futuro". Materiales de contrucción (España), N²39, 45, p.53-64 (1995).

(2) R. KONDO, S. UEDA: “Kinetics and Mechanisms of the Hydration of Cements". 5th. Intern. Symp. Chem. Cem. (Tokyo), 2, p. 203 (1968).

(3) J.H. TAPLI: "On the Hydration Kinetics of Hidraulic Cements". 5th. Intern. Symp. Chem. Cem. (Tokyo), 2, p.337 (1968).

(4) N. TENOUTASSE, A. DEDONER: “La cinétique et le mécanisme de L'Hydratation du Silicate Tricalcique”. Sil. Ind. V.35, p.301307 (1970).

(5) A. BEZJAK: "On the Determination of Rate Constants for Hydration Processes in Cement Pastes". Cem. and Concr. Res. V.10, p.553-563 (1980).

(6) A. FERNÁNDEZ-JIMÉNEZ, F. PUERTAS: “Alkali-Activated Slag Cements: Kinetic Studies”. Cem. and Concr. Res. N²7, pp. 359-368 (1997)

(7) G. SHUTTER, L. TAERWE: "General Hydration Model for Portland Cement and Blast Furnace Slag Cement". Cem. and Concr. Res. No3, 25, p.593-604 (1995).

(8) T. KNUDSEN: "On Particle size distribution in Cement Hydration”. Procg. of 7th. Inter. Congr. Chem. Cem. (París). 2, I-170175 (1980).

(9) A. FERNÁNDEZ-JIMÉNEZ, F. PUERTAS, L. FERNÁNDEZ-CARRÁSCO: "Procesos de Activación Alcalino-Sulfaticos de una Escoria Española de Alto Horno". Materiales de Construccion (España). №241, 46, p.23-37 (1996).

(10) J.H. SHARP, G.W. BRINDLEY, A.B.N. NARAHARI: "Numerical Data for some Commonly Used Solid State Reaction Equations". J. Amer. Ceram. Soc. No7, 49, p.379-382 (1966). 
(11) W. JANDER: "Reactions in the Solid State at High Temperature: I" Z. Anorg. Allgem. Chem. 163, [1-2], 1-30 (1927).

(12) A.M. GINSTLING, B.I. BROUNSHTEIN: "Concerning the Diffusion Kinetics of Reaction in Spherical Particles". J. Appl. Chem. USSR. (English Transl), 23, [12], p. 1327-38 (1950).

(I3) Z. HUANHAI, W. XUEQUAN, X. ZHONGZI, T. MINGSHU: "Kinetic Study on Hydration of Alkal-Activated Slag". Cem. Concr. Res. 23, p.1253-1258, (1993).

(14) X. WU, D.M. ROY, C.A. LANGTON: “Early Stage Hydration of Slag-Cement". Cem. Concr. Res. 13, p.227-286 (1983).

(15) M. REGOURD, H. HORNAIN, B. MORTUREAUX: Silic. Ind. 42, p. 19-27 (1977).

\section{Publicaciones del Instituto Eduardo TorrojamCSIC}

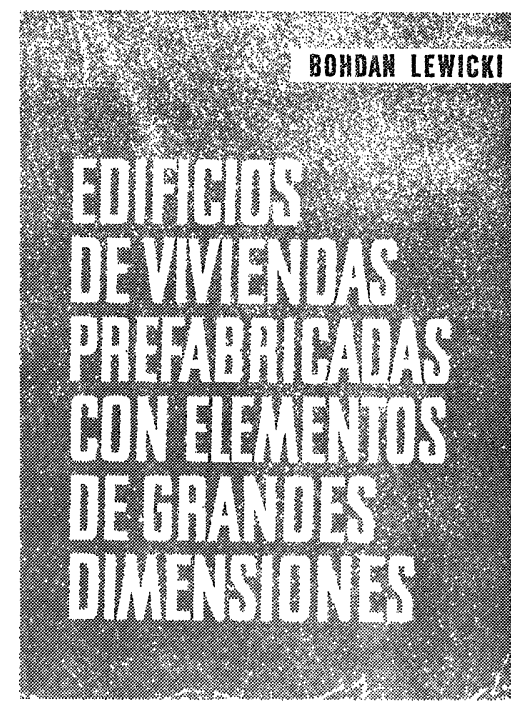

Bohdan Lewicki

Este libro trata de los problemas relativos a la construcción de los edificios de viviendas o públicos realizados con elementos prefabricados de grandes dimensiones. Se han estudiado los problemas de arriostramiento, así como los que plantea la resistencia de los elementos y de la estructura; se han examinado las cuestiones de orden higrotérmico, acústico y de resistencia al fuego; también se ha profundizado en el estudio de la estanquidad de los muros exteriores y de las juntas.

La obra incluye numerosas ilustraciones que dan detalles de diversas soluciones, asi como ejemplos de cálculo, tablas de valores numéricos, diagramas y ábacos.

Un volumen encuadernado en tela, de $24 \times 17 \mathrm{~cm}$, compuesto de 616 págs.

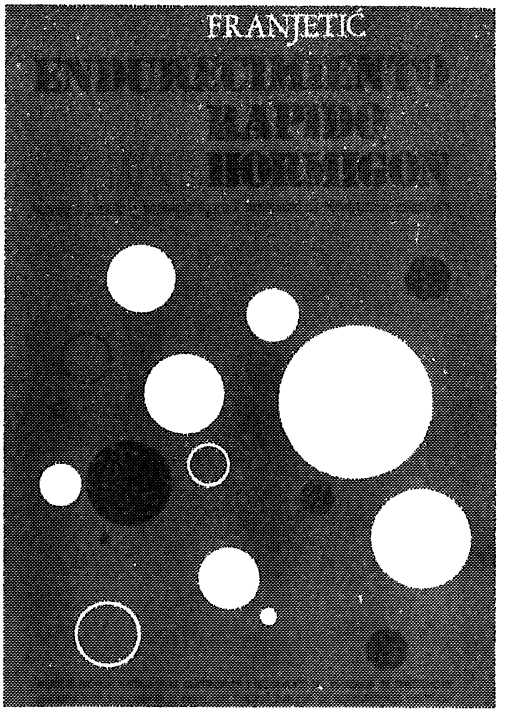

Zorislav Franjetić

En la obra de Franjetić se expone de una forma minuciosa, ordenada y sistemática, todo un cuerpo de doctrina que reúne el conocimiento actual sobre el endurecimiento rápido del hormigón. Parte el autor de los principios básicos y llega a las últimas consecuencias y realidades técnicas y eco nómicas.

Es una obra de consulta, tanto para el investigador sobre la materia como para el proyectista y el realizador y montador de plantas e instalaciones y equipos de curado y endurecimiento rápido.

Un volumen encuadernado en cartóné, de $17 \times 24,5 \mathrm{~cm}$, compuesto de 385 págs. 110 figuras y 10 tablas.

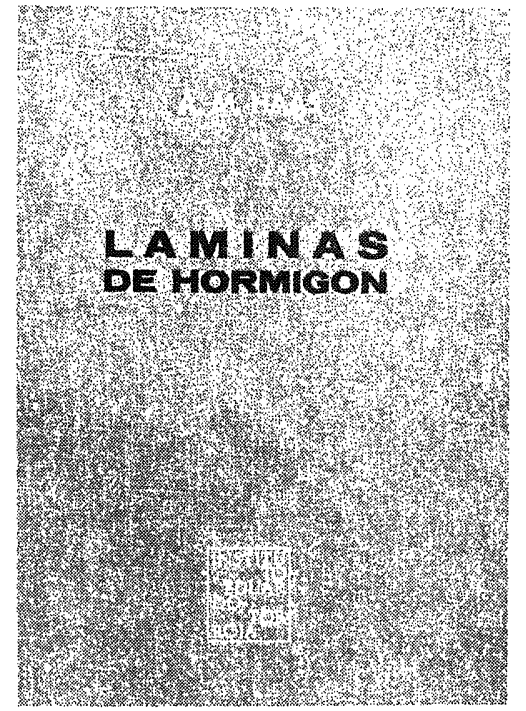

\section{A. พิ. Haas}

Al escribir este libro el autor intentó poner a disposición de los estudiantes y de los ingenieros unos conocimientos prácticos, adecuados para servir de guia en el diseño y construcción de láminas delgadas de hormigón.

El autor está convencido de que el éxito en el diseño de una lámina exige, por parte del proyectista, un examen de las tres fases por las que pasa la materialización de la iámina: el diseño, el análisis estructural y la construcción de la estructura.

Un volumen encuadernado en tela, de $17 \times 24,5 \mathrm{~cm}$, compuesto de 420 págs., 141 figuras, 22 fotografias y 6 tablas. 